\title{
The Development of Coherent Speech in Elementary School Students in The Process of Constructive and Artistic Activity
}

\section{El desarrollo del discurso coherente en estudiantes de primaria en el proceso de actividad constructiva y artística}

\author{
Valerii Budak*
}

Mykolaiv V.O. Sukhomlynskyi National University, Ukraine ORCID ID: https://orcid.org/ 0000-0003-2698-6333

\section{Nadia Lutsan iD}

Vasyl Stefanyk Precarpathian National University, Ukraine ORCID ID: https://orcid.org/0000-0001-6239-1535

\section{Tetiana Stepanova}

Mykolaiv V.O. Sukhomlynskyi National University, Ukraine ORCID ID: https://orcid.org/0000-0002-3477-1140

\section{Kateryna Shapochka}

Mykolaiv V.O. Sukhomlynskyi National University, Ukraine ORCID ID: https://orcid.org/0000-0002-4827-599X

\section{Anna Struk}

Vasyl Stefanyk Precarpathian National University, Ukraine ORCID ID: https://orcid.org/0000-0001-6442-8098

Recibido 12-12-19 Revisado 13-02-20 Aprobado 30-04-20 En línea 04-05-20

Correspondencia

Email: vbudak@bk.ru
Citar como:

Budak, V., Lutsan, N., Stepanova, T., Shapochka, K., \& Struk, A.
(2020). The Development of Coherent Speech in Elementary School
Students in The Process of Constructive and Artistic Activity.
Propósitos y $\quad$ Representaciones,
http://dx.doi.org/10.20511/pyr2020.v8n3.532 


\section{Summary}

The article examines the development of speech in elementary school students. The research objective is to determine the status of coherent speech development in 3rd-grade students in the process of constructive and artistic activity. The article defines the criteria (structural and compositional, communicative and productive, and communicative and creative), indicators, and levels of development of coherent speech in elementary school students in the process of constructive and artistic activity. Each criterion includes a group of qualitative content-disclosing indicators and characterizes the achievements of students in the intended type of activity. Based on this, the authors have developed a methodological tool that allows them to diagnose coherent speech development in 3rd-grade students in the process of constructive and artistic activity and to conduct a precise quantitative differentiation by high, sufficient, medium, and low levels of coherent speech formation with specific characteristics for qualitative measurements that open up prospects for the development of appropriate effective measures for improving the quality of training students for such activity.

Keywords: Coherent Speech; Text; Constructive and Artistic Activity; Elementary School Students.

\section{Resumen}

El artículo examina el desarrollo del habla en estudiantes de primaria. El objetivo de la investigación es determinar el estado del desarrollo coherente del habla en estudiantes de tercer grado en el proceso de actividad constructiva y artística. El artículo define los criterios (estructurales y compositivos, comunicativos y productivos, y comunicativos y creativos), indicadores y niveles de desarrollo del discurso coherente en estudiantes de primaria en el proceso de actividad constructiva y artística. Cada criterio incluye un grupo de indicadores cualitativos de divulgación de contenido y caracteriza los logros de los estudiantes en el tipo de actividad prevista. En base a esto, los autores han desarrollado una herramienta metodológica que les permite diagnosticar el desarrollo coherente del habla en estudiantes de tercer grado en el proceso de actividad constructiva y artística y llevar a cabo una diferenciación cuantitativa precisa por niveles altos, suficientes, medios y bajos de formación coherente del habla con características específicas para mediciones cualitativas que abren perspectivas para el desarrollo de medidas efectivas apropiadas para mejorar la calidad de la capacitación de los estudiantes para dicha actividad.

Palabras clave: Discurso coherente; Texto; Actividad constructiva y artística; Estudiantes de primaria.

\section{Introduction}

The ways of formation of coherent speech skills in elementary school students are studied by M. Vashulenko (2006), A. Zimuldinov (1988), N. Lvov (2000), V. Trunov (2011), and other researchers. Studies by V. Sobko are devoted to teaching school students to write descriptive texts (Sobko, 1989), teaching reasoning text writing is explored by A. Haletova (1999) and I. Holovko (1999), training students to build texts of various types is covered by V. Bader (1987), O. Hlazova (1999), and H. Shelekhova (1996), and the integration of the types of artistic activity by the means of speech development in elementary school students is researched by O. Lobanchuk (2008).

Psychologists like L. Vygotsky (1999), I. Synytsia (1965), and others understand coherent speech as the one whose form is naturally connected with and determined by its content, and 
content expresses the speaker's corresponding desire or thought. According to the definition provided by linguists, for instance, N. Lvov (2000), L. Matsko (1996), and others, coherent speech is the one in which all the types of relation defining the correlation of a statement to the objective world, the object of communication, and the laws of the language manifest itself. Researchers of the linguodidactic field of science (Bohush, 2003; Vashulenko, 2006; Lvov, 2000; Matsko, 1996, etc.) examine coherent speech as the one that is organized according to the laws of logic, grammar, and compositional unity, has a theme, serves specific functions, has relative independence and completeness, and can be divided into more or less significant structural components.

In the definition of connected speech, scientists (Lvov, 2000; Ladyzhenskaia, 1980, etc.) accentuate, on the one hand, the process of creating a statement and, on the other, the result of this process, text as the product of speech activity.

The notion of "text" is one of the central, fundamental ones in the system of working on the development of coherent speech in children. Different approaches to the study of this high level of the linguistic system have caused the emergence of several definitions. The term "text" that refers to the product of speech activity means "fabric", "plexus", "connection". Etymologically, the meaning of the term matches the nature of a language formation exactly. A linguistic dictionary provides the following definition: "Text is a unified sequence of symbolic units, the main qualities of which are coherence and integrity" (Lingvisticheskii entsiklopedicheskii slovar, 1990, p. 507).

Foreign researchers (Brown, 1997; Wittmers, 1977; Kraft, 1989; Meng, 1986; Schmidt, 1977) consider the description, narration, and reasoning as the speech and mental forms and ways of social communication.

Making a connection between the forms of speech and the process of thinking, E. Wittmers relates the forms of speech to the level of reflection of reality in human consciousness. Wittmers notes: "The level of conceptual information fundamental in nature. It includes the forms of speech as the main types of observation of reality (types of thinking) and its reproduction (the methods of text creation). The perception of reality in its spatial relationships is characteristic of description, the perception of reality in its temporal relationships is characteristic of communication, and the perception of reality in its causal relationships inherent to thinking" (Wittmers, 1977, p. 47).

In the linguodidactics of elementary school, several studies have been carried out on the development of coherent speech in students and teaching it to them, its patterns and tendencies have been revealed, and the effective ways have been identified, among which the study of various types of texts is important.

The effect of artistic activity on speech development in students is covered in a range of psychological and pedagogical studies (Vygotsky, 1999; Komarova, 1970; Sakulina, 1955; Tikheeva, 1981, etc.).

Some scientists (Grigoreva, 1998; Markova, 1983) believe a child to be poly-artistic. Their consciousness is capable of simultaneously covering all the types of artistic activity in its peculiar interweaving in the development process. Speech activity in its aesthetic aspect and the unique role in a child's life serves as one of the primary components. Thus, the harmonious interconnection of artistic activity types where speech is pivotal creates favorable conditions for the development of the ability to make coherent statements. In the process of constructive and artistic activity, students form skills allowing them to convey the content of what was seen and to implement one's ideas with the help of acquired means of expression in constructive and artistic activity. Students also develop creative abilities and symbolic functions allowing them to simulate 
objects and environmental phenomena and study them deeper. The role of constructive activity resides in the assimilation of words denoting actions and spatial relations since it presents the process of creating various structures from the corresponding materials that involve the relative position of parts and elements, as well as the ways of their combination (Uruntaeva, 1999). The process of such activity is the place of development of students' ideas and mental operations, particularly the analysis, synthesis, and generalization. The constructive activity requires the child to examine objects to identify the parts and determine the structure and the nature of the connection of individual elements.

The objective of the study is to determine the status of coherent speech development in 3 rd-grade students in the process of constructive and artistic activity.

Research tasks include identifying the criteria and indicators and conducting psychological and pedagogical diagnostics to differentiate the levels of coherent speech formation in elementary school students in the process of constructive and artistic activity.

\section{Methods}

The diagnostics of the level of coherent speech development in the process of artistic and creative activity was conducted using the authors' method (Lutsan, Kynash, 2015) considering the new requirements for the norms of assessing students' knowledge and skills (Derzhavnyi standart pochatkovoi shkoly, n.d.).

The diagnostic stage of the study involved 60 students of the Ivano-Frankivsk elementary school of general education and 60 students of the Mykolaiv elementary schools of general education studying in the 3rd grade. The sample of respondents was divided into two groups: experimental group (EG) and control group (CG).

The levels of coherent speech development in elementary school students in the process of artistic and creative activity were determined in accordance with the structural and compositional criterion (indicators: the ability to make statements consisting of three parts, the ability to use various types of connections in statements, the ability to distinguish the types of statements in texts), the communicative and productive criterion (indicators: the ability to make statements with didactic support and a situation, the ability to make instructional texts when making individual items, the ability to argue the selected type of statement), and the communicative and creative criterion (indicators: the ability to independently make statements of various types, the ability to choose appropriate types of statement in active speech, the ability to make creative statements of various types).

Each criterion includes a group of qualitative content-disclosing indicators and characterizes the achievements of students in the intended type of activity.

The above-mentioned criteria acted as a base for the development of a corresponding method for the diagnostics of coherent speech development in 3rd-grade students in the process of constructive and artistic activity.

For each of the identified criteria and indicators, the corresponding diagnostic tasks were selected that involved identifying the students' ability to distinguish the types of statements in text and make a story, description, and reasoning based on the didactic support and the situation, determining the level of oral speaking skills in the situations of unstimulated active speech, ascertaining the ability of students to make creative statements of various types in active speech, etc. 
The first series of diagnostic procedures concerned the indicators of the structural and compositional criterion.

Indicator: the ability to make a statement consisting of three parts.

Task: "Conversation on favorite game/toy".

Objective: to identify the students' ability to make statements consisting of three parts.

Procedure. The experiment was conducted in the form of a conversation. Students were asked to answer the following questions as fully as possible:

1. What game do you like to play the most? Why?

2. What is your favorite toy? Why?

3. Who is your best friend? Why?

Assessment. The answers acquired in the course of the conversation were examined as continuous statements. High level - 10 statements; sufficient level - 9-7 statements; average level -6-4 statements; low level -3-1 statements.

Indicator: the ability to use various types of connections in statements.

Task: "Embroidery". statements.

Objective: to identify the students' ability to use various types of connections in their

Procedure. Before making an embroidery, the students were asked to make statements on the topic "Traveling Snowflakes in the Winter Garden". The attention of children was directed towards the fact that they need to make statements of two types. In the first type of statement, it is necessary to state the opinion with each next sentence being connected with the previous one and in the second type of statement, the sentences should not be connected but still reveal the content of the statement as a whole.

Methodical commentary. The ability of students to make statements using the chain and the parallel connection was evaluated.

Assessment: high level - 10 statements; sufficient level - 9-7 statements; average level 6-4 statements; low level -3-1 statements.

Indicator: the ability to distinguish the types of statements in texts.

Task: "Describe, tell, think!"

Objective: to identify the students' ability to distinguish the types of statements in a text.

Procedure. Students are invited to fill a table with words describing their mother ("What is your mom like?") and the words from a story ("What can you tell about your mother?").

Assessment: Each correct answer is worth one point. Ten correct answers corresponded to the high level, 9-7 points - sufficient level, 6-4 points - average level, 3-1 points - low level. 
The second series of diagnostic procedures were aimed at identifying indicators of the communicative and productive criterion.

Indicator: the ability to make statements with didactic support and a situation.

Task: "Airplane". a situation.

Objective: to identify the students' ability to make statements with didactic support and

Materials: pre-made paper airplanes.

Procedure. The students were asked to imagine the situation: their plane could fly. It is necessary to make the statements of three types: "What is my airplane like?", "What interesting can I tell about it?", "Where will my airplane go?".

Assessment: high level - 10 statements; sufficient level - 9-7 statements; average level 6-4 statements; low level -3-1 statements.

Indicator: the ability to make instructional texts when making individual items.

Task: "Potters". jug.

Objective: to identify the students' to write instructional texts when making a plasticine

Materials: drawings of pottery, a jug, colored plasticine.

Procedure. A conversation involving the following questions was held with the students: "What is a jug?", "What is its purpose?", "What is it made of?". After answering questions, students were invited to take on the role of potters. Instruction for students: "Imagine you are potters and there is an excursion group visiting you. You need to not only show how jugs are made, but also explain how you do it. Colored plasticine will be the material for making the jugs. So, you need to explain how to prepare plasticine for modeling, how to model the jugs, and what tracery and colors should be used".

Assessment: Each correct answer is worth one point. Ten correct answers corresponded to the high level, 9-7 points - sufficient level, 6-4 points - average level, 3-1 points - low level.

Indicator: the ability to argue the selected type of statement.

Task: "Newspaper Ads".

Objective: to identify the students' ability to argue the selected type of statement.

Procedure. When making a box out of colored cardboard, the students were instructed the following: "Imagine you found the box on the street. A child must have lost it when walking with their parents. You have to post an ad to a newspaper stating that you found this box. First, you need to describe what color it is, what it is made of, how it is painted. Then you should tell where and in what condition you found it, and yet, it is worth telling what you think the box is for".

Assessment: Each correct answer is worth one point. Ten correct answers corresponded to the high level, 9-7 points - sufficient level, 6-4 points - average level, 3-1 points - low level. 
The third series of diagnostic procedures were aimed at identifying the indicators of the communicative and creative criterion.

Indicator: the ability to independently make statements of various types.

Task: "Best statement competition".

Procedure. The students were invited to go on an imaginary journey to the potters' workshop. Instruction for students: "Close your eyes. Imagine we go to a potters workshop. There are jugs, bowls, and pots on the shelves. You have to make a fairy tale with the description of these dishes, a story of what they are intended for, and reasoning about how they are made. Those who make an interesting fairy tale will get a present".

Assessment: high level - 10 statements; sufficient level - 9-7 statements; average level 6-4 statements; low level -3-1 statements.

Indicator: the ability to choose appropriate types of statements in active speech.

Task: "Radio broadcast".

Objective: to identify the students' ability to use a certain type of statement in active speech.

Procedure. Instructions for students: "Imagine you were invited to a radio broadcast about folk toys. Are you going to tell about the toys or use descriptions in your statements? How about reasoning?".

High level - 10 statements; sufficient level - 9-7 statements; average level - 6-4 statements; low level - 3-1 statements.

Indicator: the ability to make creative statements of various types.

Task "Necklace for mom".

Objective: to identify the students' ability to make various types of creative statements about their product.

Materials: a necklace.

Procedure. When making a bead necklace, the students were instructed the following: "Create a story about Mom's necklace, using narration, or description, or reasoning".

Assessment: high level - 10 statements; sufficient level - 9-7 statements; average level 6-4 statements; low level -3-1 statements.

\section{Results}

In accordance with the defined approach, the level of coherent speech development in students in the designated type of activity is characterized by the set of parameters presented by the identified criteria and indicators. The degrees of manifestation of each of the indicators taken together determine the level of coherent speech development in elementary school students in the process of constructive and artistic activity. The identified indicators served as the basis for determining 
the levels of coherent speech development in elementary school students in the process of constructive and artistic activity, namely, the high, sufficient, average, and low levels that will be characterized further.

High level. The student makes various types of statements characterized by full compositional completion; the sentences in a statement are linked using the chain, parallel, and the combination of the two types of connection; the various types of statements in a text are identified and their specific characteristics are named; the student makes a coherent statement using didactic support or a situation independently (speaking time -3 minutes); instructional texts are made independently and commented on in the course of work; the student explains the selected type of statement correctly and provides arguments; complete presentation of thought and the correspondence between the content and the type of statement are demonstrated; the student can use the types of statements appropriately in active speech; the student demonstrates initiative in the process of improvisation in making statements presenting their product.

Sufficient level. The student makes statements consisting of two parts: a thesis with a continuation or a conclusion; chain and parallel connections are made between the sentences in a statement; the student can differentiate the types of statements in a text; the student makes coherent statements based on didactic support and the situation on their own (speaking time - 12 minutes); instructional texts are made independently; the selected type of statement is explained only with the help of a teacher; independence, complete presentation of thought, and the correspondence between the content and the type of statement are demonstrated; various types of statements are used in active speech; the statements made in presenting the product are structurally correct.

Average level. The student makes statements consisting of one part or a list of nonexistent arguments; sentences in a statement are linked using one of the types of connection; the student makes mistakes in identifying the types of statements; statements are built based only on the didactic support or the situation with the help of a teacher (speaking time - 1-2 minutes); the student makes instructional texts with the help of a teacher; the types of statements are selected correctly, but the student can not explain their choice; the student is unable to make statements on their own; the student makes mistakes in selecting the type of statement in active speech and commenting on their product.

Low level. The student makes statements with the direct help of a teacher; sentences in the statement are linked using intonation and formal logical connection; the student is unable to identify the type of statement, makes mistakes when making a statement using didactic support or the situation (speaking time under 1 minute); the student is unable to make instructional texts; the student makes mistakes in selecting and explaining the statement; the statements made do not correspond to the content; the student cannot select the type of statement in active speech correctly; the student does not demonstrate initiative in making statements in the process of working on their product. Table 1 presents the levels of coherent speech development in elementary school students in the process of constructive and artistic activity by specific criteria. 
Table 1.

The levels of coherent speech development in elementary school students in the process of constructive and artistic activity (\%)

\begin{tabular}{|c|c|c|c|c|c|}
\hline \multirow{2}{*}{$\begin{array}{l}\text { Level of } \\
\text { formation }\end{array}$} & \multirow[t]{2}{*}{ Group } & \multicolumn{3}{|c|}{ Criteria $(\chi)$} & \multirow[b]{2}{*}{$\chi$} \\
\hline & & C 1 & C 2 & C 3 & \\
\hline \multirow{2}{*}{ High } & EG & 3.5 & 2.1 & 8.6 & 4.7 \\
\hline & $\mathrm{CG}$ & 3.7 & 1.7 & 7.8 & 4.4 \\
\hline \multirow[t]{2}{*}{ Sufficient } & $\mathrm{EG}$ & 10.5 & 7.8 & 20.8 & 13 \\
\hline & $\mathrm{CG}$ & 11.2 & 7.3 & 18.2 & 12.2 \\
\hline \multirow[t]{2}{*}{ Average } & $\mathrm{EG}$ & 35.6 & 13.1 & 39.7 & 29.5 \\
\hline & $\mathrm{CG}$ & 36 & 13.9 & 41.5 & 30.5 \\
\hline \multirow[t]{2}{*}{ Low } & EG & 50.4 & 77 & 30.9 & 52.8 \\
\hline & CG & 49.1 & 77.1 & 32.5 & 52.9 \\
\hline
\end{tabular}

Abbreviations:

C 1 - structural and compositional criterion;

C 2 - communicative and productive criterion;

C 3 - communicative and creative criterion;

$\chi$-arithmetic mean value.

As a result of diagnostics of coherent speech development in elementary school students in the process of constructive and artistic activity, the high level was found in $4.7 \%$ of EG students and $4.4 \%$ of CG students. The arithmetic means for the sufficient level reached $13 \%$ of EG students and $12.2 \%$ of CG students. At the beginning, the average level was reached by $29.5 \%$ of EG students and $30.5 \%$ of CG students. As we can see, the majority of students had a low level of development of skills related to making various types of statements: $\chi=52.8 \%$ of children in EG and $\chi=52.9 \%$ of students in CG. The obtained results, therefore, demonstrate the insufficient work of teachers on the development of students' skills in making statements of various types, which can be explained by content gaps and shortcomings of the educational process in elementary school and indicates the need for further improvement.

Thus, the results of psychological and pedagogical diagnostics indicate the insufficient level of coherent speech development in elementary school students in the process of constructive and artistic activity in schools of the Ivano-Frankivsk and Mykolaiv regions, Ukraine, demonstrating the need to improve student learning

\section{Conclusion}

Despite the wide variety of the examined issues, the problem of coherent speech development in the process of constructive and artistic activity in elementary school students remains unsolved: a structured methodical system aimed at the development of coherent speech not only in native language lessons but in other lessons as well, particularly in the process of constructive and artistic activity, is lacking. 
Thus, there is an evident contradiction between the modern tendencies in the development of linguistics, psycholinguistics, and linguodidactics that implicate teaching foreign languages on activity and communication basis and the insufficient development of this issue in the theoretical and methodical aspects, particularly the lack of a method for the development of coherent speech in the process of constructive and artistic activity of elementary school students which causes the overall low level of their speaking skills.

The results analysis demonstrated the levels of coherent speech development in elementary school students in the process of constructive and artistic activity being insufficient, confirming the relevance of the study of this component of elementary school students' training.

\section{References}

Bader, V.I. (1987). Grammatiko-stilisticheskii analiz teksta kak sredstvo razvitiia sviaznoi rechi mladshikh shkolnikov [Grammatical and stylistic analysis of text as a means of coherent speech development in elementary school students]: Ph.D. dissertation in pedagogics. Kyiv, 193.

Bohush, A.M., Shylina, N.Ye. (2003). Movlennieva hotovnist starshykh doshkilnykiv do navchannia u shkoli [Speech readiness of senior preschoolers to study at school]. Odesa: National Academy of Educational Sciences of Ukraine, 335.

Brown, Ch.T., Keller P.W. (1977). Monologue to dialogue. New York: Prentice-Hall, 18-48.

Derzhavnyi standart pochatkovoi shkoly [State standard for elementary school]. Retrieved from: http://nus.org.ua/news/uryad-zatverdyv-novyj-osvitnij-standart-dlya-pochatkovyhklasiv/

Grigoreva, G.G. (1998). Izobrazitelnaia deiatelnost doshkolnikov: ucheb. posobie dlia studentov sred. ped. ucheb. zavedenii [Graphic activity of preschool children: a textbook for students of secondary teacher training institutions]. Moscow: "Akademiia" Publ. Center, 272.

Hlazova, O.P. (1999). Perspektyvnist i nastupnist u formuvanni tekstotvorchykh umin v uchniv pochatkovykh i 5 klasiv zahalnoosvitnoi shkoly [Perspective and continuity in the formation of text-writing skills in elementary and 5th-grade secondary school students]: $\mathrm{Ph} . \mathrm{D}$. dissertation in pedagogics. Kyiv, 148.

Holovko, I.A. (1999). Formuvannia v molodshykh shkoliariv pochatkovykh umin i navychok skladaty tvory-mirkuvannia [The formation of basic skills of reasoning essay writing in elementary school students]: Ph.D. dissertation in pedagogics. Kyiv, 164.

Komarova, T.S. (1970). Formirovanie graficheskikh navykov u doshkolnikov [The formation of graphic skills in preschool children]. Moscow: Prosveshchenie, 152.

Kraft, B. (1989). Yemeinsames Planen bei Dreijahrigen, Zur Konzeption und zu ersten Erqebnissen einen Langsschnittunntersuchung. Linguistiscshe Studien. Vom Zentralinstitut fur Sprachwissenschaft der Akademie der Wissenschaften der DDR. Berlin, 37-54.

Ladyzhenskaia, T.A. (1980). Sviaznaia rech [Coherent speech]. Metodika razvitiia rechi na urokakh russkogo iazyka [The method of speech development in Russian language lessons]. Moscow: Prosveshchenie, 187.

Lingvisticheskii entsiklopedicheskii slovar [Linguistic encyclopedic dictionary]. (1990). Moscow: Sovetskaia Entsiklopediia, 685.

Lobanchuk, O. (2008). Intehratsiia vydiv khudozhnoi diialnosti, yak zasib rozvytku movlennia molodshchykh shkoliariv [Integration of the types of artistic activity as a means of speech development in elementary school students]: summary of a Ph.D. dissertation in pedagogics. Kyiv, 22.

Lutsan, N.I., Kynash, Yu. (2015). Kompetentnisnyi pidkhid u suchasnii pochatkovii osviti: dosvid i perspektyvy [Competence approach in modern primary education: experience and perspectives]: monograph. Ivano-Frankivsk, 256p. 
Lvov, M.R. (2000). Osnovy teorii rechi: ucheb. posob. dlia stud. vyssh. ucheb. zaved [The fundamentals of speech theory: a textbook for the students of higher education institutions]. Moscow: "Akademiia" Publ. Center, 248.

Markova, A.K. (1983). Formirovanie motivataii ucheniia v shkolnom vozraste [The formation of motivation for learning at school age]. Moscow: Prosveshchenie, 95.

Matsko, L. (1996). Ukrainska mova: formuvannia natsionalnoi svidomosti [Ukrainian language: the formation of national consciousness]. Pedahohika ta psykholohiia, 1: 67-70.

Meng, K. (1986). Sprachliche Auberung und Kommunikationssituation Vorschulkindern. Untersuchung zu den Funktionen sprachlicher Auberung bei der Losung Aufqaben in Zweierqruppen. Aufqabenbezoqene Kommunikation bei alteren Vorschulkindern. Berlin, 21-131.

Sakulina, N.P. (1955). Rol slova i nagliadnykh priemov v obuchenii risovaniiu i lepke v detskom sadu [The role of speech and visual techniques in teaching drawing and modeling in kindergarten]. Nagliadnost i slovo v khudozhestvennom vospitanii doshkolnika (metody khudozhestvennogo vospitaniia) [Demonstration and speech in the art education of a preschooler (methods of art education)]. Moscow: Publishing house of the "Novosti" Press Agency, 3-85.

Schmidt, W., Stock, E. (1977). Gespräch — Diskussion. Grundlagen und Übungen. Leipzig, 324348.

Shelekhova, H.T. (1996). Systema roboty z rozvytku zviaznoho movlennia na urokakh ridnoi movy v serednii shkoli [The system of working on speech development in native language lessons in high school]: summary of a doctoral dissertation in pedagogics. Kyiv, 45.

Sobko, V.A. (1989). Formirovanie u uchashchihsia nachalnykh klassov umenii sostavliat tekstyopisaniia [The formation of descriptive text writing skills in elementary school students]: summary of a Ph.D. dissertation in pedagogics. Kyiv, 25.

Synytsia, I.O. (1965). Psykholohiia pysemnoi movy uchniv 5-8 klasiv [The psychology of written speech of 5-8 grade school students]. Kyiv: Radianska shkola, 186.

Tikheeva, E.I. (1981). Razvitie rechi detei [Speech development in children]. Moscow: Prosveshchenie, 159.

Trunova, V.A. (2001). Rozvytok movlennia molodshykh shkoliariv v umovakh bilinhvizmu [The development of younger students' speech in the conditions of bilingualism]. Kyiv: Vyshcha shkola, 96.

Uruntaeva, M.N. (1999). Detskaia psikhologiia [Child psychology]. Moscow, 336.

Vashulenko, M.S. (2006). Ukrainska mova i movlennia v pochatkovii shkoli: metod. posib. [Ukrainian language and speech in elementary school: a method. manual]. Kyiv: Osvita, 268.

Vygotsky, L.S. (1999). Myshlenie i rech [Thinking and speech]: 5th ed. Moscow: Labirint, 351.

Wittmers, E.Zu. (1977). einiqen Aspekten der Textkomposition. Studia grammatica XVII. Berlin, 217.

Zimuldinova, A.S. (1988). Didakticheskie usloviia razvitiia sviaznoi rechi 6-letnikh uchashchikhsia [The didactic conditions for the development of coherent speech in 6year-old students]: Ph.D. dissertation in pedagogics. Kyiv, 199. 